\title{
Perkembangan Spiritual Remaja dalam Perspektif Ahli
}

\author{
Sugeng Sejati. ${ }^{1}$ \\ IAIN Bengkulu \\ Jl. Raden Fatah Pagar Dewa Kota Bengkulu
}

\begin{abstract}
Youth Spiritual Development in Expert Perspectives. Spiritual development actually provides direction and life meaning for a teenager's about the belief in the existence of a non-physical power that is greater than his strength. An awareness that connects youth directly with God, or whatever we call the source of our existence, Spiritual also means psychological, spiritual, mental, and moral. This means that when a teenager is always worshiping God, he is present spiritually in the personal identity. The Spiritual has mean that teenagers are personally able to actualize divine values as a manifestation of activities in daily life, where to be a spiritual individual requires an effort to awaken the deepest soul, namely by arousing self-motivation, self-awareness, reviving the vision and value, full of responsibility, independence, and maintaining ukhuwah.
\end{abstract}

Abstrak: Pekembangan Spiritual sesungguhnya memberikan arah dan arti bagi kehidupan remaja tentang kepercayaan mengenai adanya kekuatan non fisik yang lebih besar dari pada kekuatan dirinya. Suatu kesadaran yang menghubungkan remaja langsung dengan Tuhan, atau apapun yang kita namakan sebagai sumber keberadaan kita, Spiritual juga berati kejiwaan, rohani, batin, mental, dan moral. Artinya ketika diri remaja selalu beribadah kepadah Allah maka hadir spiritual pada identitas diri pribadi. Spiritual yang dimaksud disini adalah remaja secara pribadi mampu mengaktulisasikan nilai-nilai Illahiah sebagai manifestasi dari aktifitas dalam kehidupan seahari-hari, dimana untuk menjadi individu yang spiritual memerlukan suatu usaha untuk membangkitkan jiwa yang paling dalam yaitu dengan membangkitkan motivasi diri, kesadaran diri, menghidupkan visi dan nilai, penuh tangung jawab, mandiri, dan menjaga ukhuwah. 


\section{A. Spiritual}

\section{Pengertian Spiritual}

Menurut Webster kata “ spirit" berasal dari kata benda bahasa latin "spritus" yang berarti napas dan kata kerja "spirare" yang berarti untuk bernapas, melihat asal katanya, untuk hidup adalah untuk bernapas dan memiliki napas artinya memiliki spirit. Menjadi spiritual berarti memiliki ikatan yang lebih kepada hal yang bersifat kerohanian atau kejiwaan dibandingkan hal yang bersifat fisik atau material. Spiritual merupakan kebangkitan atau pencerahan diri dalam mencapai tujuan dan makna hidup. Spritual merupakan bagian enseial dari keseluruhan kesehatan dan kesejatraan seseorang. ${ }^{2}$ Sedangkan dalam kamus bahasa Indonesia istilah spirit diartikan sebagai semangat; roh, jiwa dan suka, sedangkan spiritual berkaitan dengan kejiwaan dan berhubungan dengan kerohanian. $^{3}$ Dalam kamus psikologi spirit suatu zat atau mahluk immaterial, biasanya bersifat ketuhanan menurut aslinya, yang diberi sifat dari banyak ciri karakteristik manusia, kekuatan, tenaga, semangat, vitalitas energi, moral atau motivasi. ${ }^{4}$

Spiritual dalam artian yang luas merupakan suatu hal yang berhubungan dengan spirit. Seuatu yang spiritual memiliki kebenaran abadi yang berhubungan dengan tujuan hidup manusia, sering dibandingkan dengan sesuatu yang bersifat duniawi dan sementara. Didalamnya mungkin terdapat kepercayaan terhadap kekuatan supernatural seperti dalam agama, tetapi memiliki penekanan terhadap pengalaman peribadi. Spiritualitas dapat merupakan ekspresi dari kehidupan yang dipersepsikan lebih tinggi, lebih kompleks atau lebih terintergrasi dalam pandangan hidup seseorang, dan lebih daripada hal yang bersifat indrawi. Salah satu asfek dari menjadi spiritual adalah memiliki arah tujuan, yang secara terus menerus meningkatkan kebijaksanaan dan kekuatan berkehendak dari seseorang, mencapai 
hubungan yang lebih dekat dengan ketuhanan dan alam semesta, dan menghilangkan ilusi dari gagasan salah yang berasal dari alat indra, perasaan dan pikiran. ${ }^{5}$

Selanjutnya fihak lain mengatakan bahwa spiritual memiliki dua proses. Pertama proses keatas, yang merupakan tumbuhnya kekuatan internal yang mengubah hubungan seseorang dengan tuhan. Kedua proses kebawah yang ditandai dengan peningkatan realitas fisik seseorang akibat perubahan internal. Konotasi lain, perubahan akan timbul pada diri seorang dengan meningkatnya kesadaran diri, dimana nilai-nilai ketuhanan didalam akan termanifestasi keluar melaui pengalaman dan kemajuan diri. ${ }^{6}$ Spiritual ini memberikan arah dan arti bagi kehidupan kita tentang kepercayaan mengenai adanya kekuatan no fisik yang lebih besar dari pada kekuatan diri kita. Suatu kesadaran yang menghubungkan kita langsung dengan Tuhan, atau apapun yang kita namakan sebagai sumber keberadaan kita, Spiritual juga berati kejiwaan, rohani, batin, mental, dan moral.

Selanjutnya

Ary

Ginanjar Agustian beliau juga mendefinisikan bahwa kecerdasan spiritual adalah kemampuan untuk memberi makna ibadah pada setiap perilaku dan kegiatan melalui langka-langka dan pemikiran yang bersifat fitrah, menuju manusia seutuhnya hanif dan memiliki pemikiran tauhid intergralistik serta berprinsip hanya karena Allah.7

Menurut

Khalil

Kavari, apabila manusia gagal dalam mencapai makna hidupnya, mereka akan menderita kekeringan jiwa, seperti yang banyak terjadi disekitar dewasa saat ini ${ }^{8}$. Hal ini terjadi akibat kesalahan orientasi dalam menjalani kehidupan ini. Mereka menyangka bahwa makna kehidupan bisa diraih melalui materi, tetapi pada kenyataan mereka gagal menemukan makna kehidupan hakiki yang sesungguhnya, lewat materi tersebut. Merujuk pada Khalil Khavari beliau juga mengemukakan bahawa spiritual itu merukana suatu dimensi non material kita-ruh 
manusia. Inilah intan yang belum terasa yang kita semua miliki. Kita harus mengalinya seperti apa adanya, mengosoknya sehingga mengkilap denagan tekat yang besar dan mengunakan untuk memperoleh kebahagiaan abadi. $^{9}$

Menurut Suharsono kecerdasan spiritual merupakan suatu kecerdasan yang berasal dari fitrah Allah yang tidak dapat dibentuk melalui kursus-kursus atau penumpukan memory fenomenal, tetapi merupakan aktualisasi fitrah manusia. Kemampuan ini akan teraktualisasi secara nyata bila manusia menjalani hidupnya secara spiritual dengan memperbanyak ibadah wajib dan sunah, serta melakukan kegiatan penyucian diri(tazkiatun nafs). Upayaupaya seperti inilah yang sesungguhnya mampu mengundang campur tangan illahi dalam bentuk inspirasi dan tindakan-tindakan kreatif. 10

Dari pendapat di atas penulis melihat bahwa aktulisasi fitra manusia itu di dapat dari upaya diri pribadi dalam mendekatkan diri kepada Allah. Artinya ketika diri individu selalu beribadah kepadah Allah maka hadir spiritual pada identitas diri pribadi.

Sedangkan menurut Doe sebagai dasar bagi tempat tumbuhnya harga diri, nilainilai, moral, mampu memberikan arah terhadap kehidupan manusia, serta adanya suatu keyakinan bahwa adanya kekuatan nonfisik yang maha sempurna diluar diri manusia yaitu (Allah), tetapi kecerdasan spiritual itu justru tidak berkaitan dengan asfek agama, begitu juga dengan pendapat Zohar dan Ian Marsal. Namun Tamara berpendapat bahwa kecerdsan spiritual yang berasal dari barat tidak serta merta berangkat dari nilainilai keagamaan, hal itu hanya dipandang sebagai kajian dalam persfektif humanisme, dan sebuah kenyataan yang melekat pada diri manusia ${ }^{11}$. Maka untuk mengakomodir dari pesan-pesan Al-Qur'an pengunaan istilah SQ dikembangkan menjadi kecerdasan ruhaniah "trancendental intelligence" 
yaitu kemampuan seorang untuk mendengarkan hati nuranihnya dlam mengambil suatu keputusan. Keputusan tersebut akan diwujudkan dalam bentuk aktivitas yang bermakna dalam kehidupan manusia.

Pengertian

lain menjelaskan bahawa kecerdasan spiritual merupakan suatu kecerdasan yang memberikan kita makna, melakukan kontekstualsasi dan bersifat transformatif (our meaning-giving, contextualizing and transformative intelligence) diman kecerdasan yang fleksibel, adaftif, dan bergerak dengan penuh kesadaran dalam merespon semua pengalaman-pengalamanpengalaman yang kita alami secara tepat. ${ }^{12}$ Kecerdasan spiritual ini tidak bisa berdiri sendiri (tampa IQ dan EQ), karena kecerdasan spiritual ini merupakan jenis kecerdasan yang akan berperan untuk memfasilitasi terjadinya dialog antara kecerdasan intelektual dan kecerdasan emosional.SQ merupakan jenis kecerdasan yang bisa memberikan arti yang lebih mendalam terhadap kecerdasan IQ dan
EQ. Dengan bahasa yang lebih sederhana. SQ adalah kecerdasan berhubungan erat dengan bagaimana mengahadapi persoalan makna hidup atau bagaiman hidup menjadi lebih bermakna. ${ }^{13}$

Danah Zohar dan Ian Marsal mengatakan bahwa:

By SQ I mean the intelligence with wich we address and salve problems of meaning and value, the intelligence with which we can place our action and our lives in a wider, richer, meaning and giving context, tehe intellegence with which we can assess that one course of action or one lifepath is more meaningful that other.

(Yang saya maksudkan dengan SQ adalah kecerdasan yang dengannya kita bisa mengarahkan dan memecahkan persolanpersoalan makna dan nilai, yaitu kecerdasan dengannya kita menempatkan perilaku dan hidup kita dalam konteks makna yang lebih luas dan kaya, kecerdasan untuk menilai bahwa hidup seseorang lebih bermakna bila dibandingkan dengan yang lain. Spiritual 
\begin{tabular}{lcr} 
adalah landasan & yang \\
diperlukan & \multicolumn{4}{r}{ untuk } \\
mempungsikan & IQ dan & EQ \\
secara efektif & bahkan & SQ \\
merupakan & kecerdasan \\
tertinggi. ${ }^{14}$ & &
\end{tabular}

Dalam terminologi Islam dapat dikatakan bahwa SQ adalah kecerdasan yang bertumpu pada qalb. Qalb inilah yang sebenarnya merupakan pusat kendali semua gerak anggota tubuh manusia. Ia adalah raja bagi semua anggota tubuh yang lain. Semua aktivitas manusia berada dibawah kendalinya. Jika qalb ini sudah baik maka gerak dan aktivitas angota tubuh yang alain akan baik pula. Demikian pula sebaliknya

Dalam islam adalah islam itu sendiri yang mempersentasikan ajaran-ajaran yang bersifat holistik dan intergral. Ia menyangkut tidak hanya dimensi lahir tetapi juga yang lebih utama adalah dimensi batin, ia adalah kebenaran multlak. Ia adalah perwujudan kedekatan pada Yang Maha Pencipta, ia adalah ke imanan, ia adalah ketakwaan, ia adalah ketawadhua'an., ia adalah pengabdian dan penyembahan. ${ }^{15}$

Maka dengan demikian jika ingin mendapatkan spiritual kita harus berislam. Jika ingin meningkatkan spiritual maka perlu meningkatkan pelaksanaan ajaran islam, maka kita perlu menyerahkan diri sepenuhnya dalam islam. Islam agama kita, agama yang mengajarkan kebenaran dan petunjuk dalam mencapai kebahagiaan hidup baik didunia maupun di akhirat. Kekuatan spiritual itu akan didapat manakala kita kuat dalam mengikuti dan melaksanakan ajaran-ajarannya tidak lain ajaran islam itu sendiri. 16

Ketika melihat sejarah penciptaan manusia, diketahui bahwa pada mulanya manusia berada ditempat yang tinggi sebagai mahluk spiritual murni, yang kemudian spiritual itu ditiupkan kedalam tubuh manusia. Sifat-sifat spiritual itu dipadukan ke dalam materi kongret berupa tubuh atau jasad manusia yang terbuat dari tanah. Maka lahirlah manusia yang tidak hanya memiliki tubuh tetapi juga memiliki sifat spiritual yang mana kita ketahui 
teori ini menyanggah teori Darwin yang hanya melihat manusia dari sisi fisiologis saja, dan mengabaikan sisi spiritual dalam diri manusia ${ }^{17}$. Pendapat ini dapat dibuktikan dengan adanya penemuan ilmiah SQ ( Spiritual Quotien) di California University oleh V.S Ramachandra pada tahun 1997. Penemuan tersebut menekankan tentang adanya God Spot pada otak manusia yang kemudian dijelaskan lebih lanjut sebagai wadah yang memiliki potensi spiritual. Juga penenmuan Michael Pesinger, Wolf Singger, dan Rodolfo Llinas tentang osilasi saraf spiritual. Dengan demikian para ahli tersebut telah berhasil menenmukan bahwa pada diri manusia memiliki unsur-unsur spiritual, yang berfungsi sebagai pusat makna tertinggi dalam kehidupan manusia (The Ulimate Meaning). ${ }^{18}$

Kebutuhan akan spiritual adalah kebutuhan untuk mempertahankan keyakinan, mengembalikan keyakinan, memenuhi kewajiban agama, serta untuk menyeimbangkan kemampuan intelektual dan emosional yang dimiliki seseorang, sehingga dengan kemampuan ini akan membantu mewujudkan pribadi manusia seutuhnya. Sebagaimana yang disebutkan dalam firmanya Allah SWT dalam Q.S Al-Jum'ah. 62:2 yang berbunyi:

"Dialah yang mengutus kepada kaum yang buta hurup seorang rasul diantara mereka, yang membacakan ayat-ayatNya kepada mereka, mensucikan mereka dan mengajarkan mereka kitab dan hikmah (As Sunnah). Dan sesunguhnya mereka sebelumnya benar-benar dalam kesesatan yang nyata"19

Dengan demikian kita melihat bahwa spiritual dalam islam indentik dengan suatu kecerdasan ruhaniah yang pada dasarnya tahap pencerdasan ini dapat kita mulai sejak pra kehamilan, kemudian kita teruskan pada saat kehamilan, dan terus dibangun sejak balita hingga dewasa. Maka makna hidup manusia dengan demikian terletak pada tingkat spiritualitas yang dimiliknya. Ada bagian manusia berpendapat yang dicapi dalam proses pembinaan spiritual tersebut tuhan yang 
sebenarnya. Bahkan sebagai tenaga pengerak untuk membentangkan cela dari masa lalu kemasa depan, merupakan bagian dari proses yang berlangsung selama miliyaran tahun dan masih berlangsung hingga sekarang yang dengan itu alam semesta menyadari akan berpengaruh pada penyikapan penciptaan. Jika perubahan quantum dalam kesadaran semacam itu benar-benar terjadi, itu mewakili kemenangan heroik atas determinisme, bukan atas alam melainkan akan batasanbatasan pikiran sendiri yang mencegah untuk berkerja secara selaras dengan alam semesta.

Umat muslim yang menyakini eksitensi Allah selaku penciptanya, maka pada dirinya tumbuh spiritualitas tersebut. Keinginan mempertahankan keyakinan dalam diri bahwa kehidupan ini ada yang mengatur dan mengendalikannya itupun merupakan cabang dari spiritualitas. Pengabdian diri seutuhnya terhadap Ilahi merupakan hasil dari kerja keras spiritual yang membumi pada setiap jiwa. Ketenangan yang dimiliki yang individu akan terpancar pada wajahnya berupa kesejukan, pada sikapnya berupa ketawadhu'an, pada keinginanya berupa keinginan kebahagiaan orang lain, pada gerakanya berupa kebijakan, pada amalnya berupa keshalihan dan pada budi pekertinya berupa akhlak yang mulia.

Seorang yang berahlak mulia, jiwa akan sehat dan spiritual kuat, dan apabila jiwa sehat dan spiritual kuat manusia mampu merasakan kebahagiaan dalam hidup, maka ia akan sampai pada kesempurnaan (insan kamil). "Insan Kamil dalam tasawuf Islam adalah manusia yang mudah berkomunikasi dan mendekatkan diri pada Allah. ${ }^{20}$

Dengan demikian dari uraian diatas dapat disimpulkan spiritual yang dimaksud penulis disini adalah sesuatu individu yang secara pribadi mampu mengaktulisasikan nilai-nilai Illahiah sebagai manifestasi dari aktifitas dalam kehidupan seahari-hari dimana untuk 
menjadi individu yang spiritual memerlukan suatu usaha untuk membangkitkan jiwa yang paling dalam yaitu dengan membangkitkan motivasi diri, kesadaran diri, menghidupkan visi dan nilai, penuh tangung jawab, mandiri, dan menjaga ukhuwah. Kemampuan memotivasi diri yang dimaksud penulis adalah suatu kemampuan dimana individu menyadari akan pencarian makna hidup, memiliki intergritas dan memiliki komitmen serta memiliki pengembangan diri. Kesadaran diri yang tinggi membuat individu mempunyai pemahaman tentang siapa dirinya, dan apa makna segala sesautunya. Oleh karena itu individu perlu menyadari sejauh mana kelemahan dan kekurangan yang mereka miliki dan menyadari batas suasana yang mereka senangi.selanjudnya menghidupkan visi dan nilai adala suatu rencana kedepan kemanah arah individu bertindak dimana tindakan individu yang dilakukan harus sesuai dengan nilai-nilai moral dan agama sehingga apa yang dilakukan dapat diterima oleh semua kalangan.Penuh rasa tangung jawab merupaka suatu yang harus dimilki indivu dimana individu yang bertangung jawab berarti individu ini telah mampu memikul segala resiko yang telah terjadi atas dirinya, lingkunganya, maupun terhadap orang lain dan tidak menyalahkan orang lain. Sedangkan mandiri yang dimaksud penulis adalah suatu individu yang memiliki pola pikir yang kreatif, bertindak secara mandiri tidak tergantung dengan orang lain dan selalu idealis dalam prisip yang ia yakini kebenarannya serta tidak terpengaruh atas pendapt pendapat yang dikemukan orang lain. Terakhir individu yang selalu menjaga ukhuwah yaitu individu akan menyadari ketika individu merugikan orang lain berarti telah merugikan dirinya sendiri artinya individu ini mampu melihat dirinya pada orang lain.

\section{Karakteristik Spiritual}

Karakteristik berasal dari kata dasar karakter yang berarti watak, akhlak atau 
budi perekerti yang membedakan antara individu yang satu dengan individu yang lain sedangkan menutur istilah psikologi karakter berarti alasana-alasan yang disadari yang tidak disadari yang mendorong individu untuk melakukan suatu tindakan ${ }^{21}$.

Dengan demikian karakteristik spiriitual individu yang penulis maksud adalah sebagai berikut :22

Menurut Robert A. Emmos sebagaimana dikutif oleh Jaludin Rahmat bahwa karakteristik Spiritual itu terdiri dari ;

a. Kemampuan individu mentransendensikan yang fisik dan material

b. Kemampuan individu yang mengalami tingkat kesadaran yang memuncak

c. Kemampuan individu mengsakralkan pengalaman sehari-hari

d. Kemampuan individu untuk berbuat baik, yaitu memiliki rasa jkasih sayang yang tinggi pada sesama mahluk tuhan seperti memberi maaf, bersyukur, atau mengungkapkan terimahkasih, bersikap rendah hati, menunjukan kasih sayang dan kearifan, hanyalah sebagai dari kebijakan.

Selain itu terdapat empat karakteristik spiritual yang dikemukakan oleh Abdul hasan dalam bukunya SQ Nabi, Adapun karakteristik Spiritual tersebut adalah sebagai berikut :

a. Pada diri individu memiliki suatu prinsip hidup dan pegangan hidup yang jelas dan kuat yang berpijak pada kebenaran universal baik yang berupa cinta, kasih sayang, keadilan, kejujuran, toleransi, integritas, dan lainlain. Semua itu menjadi bagian terpenting dalam kehidupanya , yang sedetikpun bisa dipisahkan darinya dengan prinsip hidup yang kuat tersebut, ia menjadi orang yang betulbetul merdeka dan tidak akan diperbudak oleh siapa atau apapun. Ia bergerak dibawah bimbingan dan kekuatan prinsip yang menjadi pijakannya. ${ }^{23}$
b. Individu
memiliki
kemampuan
untuk menghadapi dan memanfaatkan penderitaan 
Perkembangan Spiritual Remaja dalam Perspektif Ahli

dan memiliki kemampuan untuk menghadapi dan melampaui rasa sakit (tranced pain). Berbagai penderitaan, halangan, rintangan dan tantangan yang hadir dalam kehidupannya dihadapi dengan penuh senyuman dan keteguhan hati karena itu semua adalah bagian dari proses menuju kematangan kepribadian secara umum baik kematangan

intelektual,mental dan moral-sosial.

c. Individu mampu memaknai semua perkerjaan dan aktivitasnya dalam kerangka dan bingkai yang lebih luas dan bermakna ${ }^{24}$.

d. Individu memiliki kesadaran diri yang tinggi maksudnya apapun yang ia lakukan itu dengan penuh kesadaran. Dia sadar dalam kesadaran tersebut. Seperti yang ditegaskan Danah dan Zonar dan Ian Marsal yaitu Bahwa Manusia ini berbeda dengan mesin. Manusisa adalah mahluk yang memiliki kesadaran (human being are conscious)." 25

Selain itu karakteritik spiritual yang utama meliputi perasaan keseluruan dan keselarasan dalam diri seorang, dengan orang lain, dan dengan Tuhan atau kekuatan tertinggi sebagai satu penetapan. Orang-orang menurut tingkat perkembangan mereka, pengalaman secara total dengan hidup atau jawaban yang mereka miliki. seperti setiap hidup individu berkembang secara normal, timbul situasi yang menyebabkan kecemasan, tidak berdaya, atau kepusingan. ${ }^{26}$

Dalam buku SQ Danah Zohar dan Ian Marsal Mengemukakan tanda-tanda spiritual yang berkembang dengan baik mencakup hal-hal sebagai berikut: 27

a. Kemampuan bersikap fleksibel.

b. Tingkat kesadaran yang tinggi.

c. Kemampuan menghadapi untuk menghadapi dan 
memanfaatkan

penderitaan.

d. Kemampuan

untuk

menghadapi dan

melampaui rasa sakit.

e. Kualitas hidup di ilhami oleh visi dan nilai-nilai.

f. Keengganan untuk menyebabkan kerugian yang tidak perlu.

g. Kecendrungan untuk melihat keterkaitan antara berbagai hal.

h. Menjadi apa yang yang disebut para psikologi sebagai bidang "Mandiri"

Sedangakan dalam

God Spot terdapat 33 Drive Suara Hati yang terdapat dalam kepribadian individu yaitu; 28

1. Pengasih, dorongan untuk menyayangi sesama ihsan kepada Ar-Rahman.

2. Mampu menguasai diri kemapuan untuk merendam bahwa nafsu adalah wujud ihsan kepada Al-Maalik

3. Berhati jernih, bebas dari iri, dengki paradigma negatif, adalah wujud dari ihsan kepada Al-Qudus.

4. Cinta damai, tidak suka kekerasan, dan selalu ingin kedamaian, adalah wujud ihsan kepada As-Salam.
5. Dipercaya, memiliki sifat amanah atau accuntable, adalah wujud ihsan kepada Al-Mukmim

6. Kreatif, Senantiasa produktif dengan ide-ide baru adalah wujud ihsan kepada AlKhaliq.

7. Pemaaf, mudah menerima maaf adalah wujud ihsan kepada Al-Gafar.

8. Murah hati, suka memberi dengan iklas adalah wujud ihsan kepada Al-Wahhab.

9. Terbuka, mau menerima kritik dan saran adalah wujud ihsan kepada AlFatah.

10.Disiplin, mengerjakan tugas dengan disiplin dan tangung jawab adalah wujud ihsan kepada Al-Mattin.

11.Empati/peduli, mampu merasakan suara hati orang lain adalah wujud ihsan AlSaami.

12.Objektif, tidak dipengaruhi pandangan dan kepentingan pribadi adalah wujud ihsan kepada Al-Haqq.

13.Adil, meletakan segalanya sesuai dengan porsinya adalah wujud ihsan kepada Al-Adl.

14.Mensyukuri, menerima segala hal dengan iklas 
adalah wujud ihsan kepada Al-Syakuur.

15.Berfikir maju, memiliki visi kedepan adalah wujud ihsan kepada Al-Aakhir.

16.Luas hati, dapat menerima kenyataan dengan berlapang dda, sabar adalah wujud ihsan kepada Al-Wakiil.

17.Bertangung jawab, mampu menyelesaikan semua tugas secara tuntas adalah wujud ihsan kepada Al-Wakiil.

18.Komitmen Tinggi, biasa memegang janji adalah wujud ihsan kepada $A l$ Muqiit.

19.Kokoh, teguh dalam berusaha adalah wujud ihsan kepada Al-Qawiyy.

20.Mandiri, dapat diandalkan adalah wujud ihsan kepada Al-Qayuum.

21.Kompeten, ahli dibidangnya adalah wujud ihsan kepada Al-Qadir.

22.Cerdas, senantiasa memiliki keinginan untuk belajar adalah wujud ihsan kepada Ar-Rasyiid.

23.Berani , mengambil keputusan adalah wujud ihsan kepada Al-Hakam.

24.Enerjik, senantiasa bersemangat adalah wujud ihsan kepada Al-Azis
25.Suka mendukung adalah wujud ihsan kepada Al-Raafi.

26.Kooperatif, suka berkerja sama adalah wujud ihsan kepada Al-Jaami.

27.Dermawan adalah wujud ihsan kepada Al-Barr

28.Pemebri manfaat, di manapun berada ia selalu berguna adalah wujud ihsan kepada Al-Naafi.

29.Inspirator adalah wujud ihsan kepada Al-Waarits.

30.Estetis, rafi dan bersih adalah wujud ihsan kepada Al-badii

31.Pendelegasi, senantiasa memiliki kemauan untuk mengajari bawaan adalah wujud ihsan kepada AlWaarits.

32.Waspada, berhati-hati dalam setiap langka adalah wujud ihsan kepada Al-Khaabir.

33.Sabar adalah wujud ihsan kepada Ash-Shabuur.

Dari penjelasan diatas menurut penulis karakteristik yang disebutkan itu merupakan suara hati yang terdapat dalam kepribadian pada setiap individu. Ketika suara hati itu sudah tertanam pada diri individu maka terbentuklah identitas diri 


\begin{abstract}
pada setiap individu tersebut.

Berdasarkan berbagai macam karakteristik spiritual diatas dapat penulis simpulkan bahwa karakteristik spiritual itu merupakan suatu kepribadian yang dimiliki individu dimana pribadi individu merasakan suatu kehadiran tuhan atau mahluk ruhaniayah yang disekitarnya mengalami transedental fisikal dan material. Dimana individu tersebut mencapai suatu kesadaran yang tinggi.
\end{abstract}

\title{
B. Perkembangan Spiritual Remaja
}

1. Tahap Spiritual Perkembangan Flower

Menurut James W. Flower mengembangkan suatu tahap perkembangan dalam keyakinan seseorang (stages of faith development) sepanjang rentang kehidupan manusia beliau mengemukakan kepercayaan merupakan orientasi holistik yang menunjukan hubungan antara individu dalam alam semesta. ${ }^{29}$
Tahap perkembangan spiritual menurut teori membagi ada enam tahapan perkembangan spiritual diantaranya meliputi kepercayaan intuitif-froyektif (intuitive-projective) tahap dimana masih terdapat karakter kejiwaan yang belum terlindungi dari ketidak sadaran, dimana anak masih belajar untuk membedakan khayalan dengan realitas yang sesunguhnya biasanya rentang usianya adala 3-7 tahun, yang kedua tahap kepercayaan mythikal literal (mytthical-literal) yaitu suatu tahap dimana seorang telah mulai mengembangkan keimanan yang kuat dalam kepercayaannya., dimana anak sudah mulai mengalami ketergantungan dengan alam semesta namun ia masih melihat kekuatan kosmik dalam bentuk seperti yang terdapat pada manusia. Rentang usianya terjadi pada usia sekolah.Ketiga yaitu tahap kepercayaan sintetik konvesional (syntheticcoventional) yaitu suatu tahap dimana seorang menegembangkan karakter keimanan terhadap kepercayaan yang dimilikinya, 
dimana ia mempelajari keimanan dari orang lain disekitarnya, namum masih terbatas pada sistem kepercayaan yang sama.Keempat tahap kepercayaan ividuatif-relektif (individuative-reflective)

merupakan suatu tahapan pecobaan dan pergolakan, dimana individu mulai mengembangkan tangung jawab pribadi terhadap kepercayaan dan perasaannya. Kelima tahap konjungtif (conjunctive) yaitu tahap individu mulai mneal berbagai pertentangan yang terdapat dalam realitas kepercayaanya. Keenam tahap universal (universalizing) yaitu suatu tahapanyang dikenal dengan pencerahan. Manusia mengalami transendensi pada tingkat pengalaman yang lebih tinggi sebagai hasil dari pemahaman terhadap lingkungan yang konfliktual dna penuh parakdosal.

Dari teori di atas penulis menyimpulkan bahwa proses perkembangan spiritual yang dikemukakan oleh Folwer merupakan suatu proses perkembangan yang berhenti pada tahap ke empat karena tahap keempat merupakan suatu tahap munculnya suatu kemantangan diri individu sehingga untuk melanjudkan melangka kedepanya individu butuh suatu padangan yang lebih luas untuk mencapi suatu jalan kehidupan yang seutuhnya.

\section{Tahap Perkembangan Spiritual Menurut Peck}

Menurut teori M. Scott Peck perkembangan spiritual itu bersifat sukarela artinya seorang akan mengalami perkembangan spiritual atau tidak adalah merupakan pilihan otonom $^{30}$. Dari pendapat Peck tersebut penulis menemui beberapa tahap perkembangan yaitu ;

a. Kekacauan/Antisosial (Chootic/Antisosial)

Individu yang berada dalam pada tahap perekembangan ini memiliki karakteristik yang bersifat egosentris, berpokus pada diri sendiri dan hanya mementingkan pada pemuasan sendiri31.Tahap perkembangan ini dikenal dengan orang-orang yang kriminal dalam bahasa yang dikemukakan oleh Peck misalnya seperti individu 
yang mengalami kecanduan obat, dan mereka selalu menyakiti orang laian; yang menghalalkan berbagai cara untuk kepentingan pribadi, sebaliknya individu ini tidak mau melakukan hal-hal yang merupakan kepentingan terbaik bagi masyarakat masyarakat secara keseluruhan. Kehidupan mereka membingungkan, penuh kekacauan dan menyakitkan.

Dengan demikian menurut penulis kekacauan yang dikemukakan oleh Peck adalah suatu kpribadian individu yang tidak memiliki konsep pribadi yang pasti terhadap tuhan, walaupun kita lihat individu tersebut mengakui adanya Tuhan, akan tetapi individu itu sendiri tidak sama sekali dapat menghubungkan dengan keberadaan diri mereka sendiri.

b. Formal/Institusional (formal/institutional)

Tahap perkembangan formal/institusional ini merupakan suatu tahapan yang berfungsi bagi pribadi individu yang mengalami kebingungan dan tangung jawab pengasuhan, pembayaran tagihan dan persyaratan untuk memiliki perkerjaan tetap. Kita bebas dari kontrol orang tua, mereka mencari figur orang tua dalam bentuk instituisi yang dapat mengarahkan prilaku mereka dan memberikan ganjaran pelanggaran disiplin.

Dengan

demikian menurut penulis terlihat jelas bahwa formal/institusional yang dimaksud di atas adalah pribadi yang membutuhkan suatu tauladan dalam mengarahkan suatu tindakan yang dilakukan sehingga pribadi individu menyadari akan apa yang diperbuat dan siap menerima sanksi apabila melakukan suatu kesalahan.

c. Skeptik/Individual (Skeptic/Individual)

Tahap perkembangan ini merupakan suatu tahapan dimana individu disini telah dapat mengatur diri sendiri dan tidak membutuhkan orang tua. Artinya disini pribadi individu telah memiliki ikatan terhadap tujuan hidup dan bahkan takdir. Dimana mereka sering menekankan pada karakteristik cinta, kebaikan 
hati dan menghindarkan diri dari menyakiti orang lain.

d. Mistikal/Komunal (Mystical/Communal)

Tahap perkembangan ini merupakan suatu tahapan yang mengambarkan pada diri individu yang berada pada tingkat perkembang pspiritual. Maksudnya adalah dimana individu hidup dalam paradoks dan seringkali dikotomi keseimbangan sebagai suatu yang bertentangan. Mereka melihat bahwa kehidupan dari sudut humor, meskipun bagi kebanyakan orang situasi tersebut menimbulkan frustasi. Mreka memiliki pandangan global yang terdapat pada kejadian tunggal. Mereka memiliki visi jangka panjang dan pemahaman terhadap dinamika masing masing peristiwa .Mereka menanamkan kebijaksanaan dan menganjurkan kesatuan sehingga memiliki kontribusi pada kesehatan sosial.

Dapat disimpulkan menurut penulis bahwa tahap ini merupakan tahap dimana mereka memiliki kebahagiaan dan penyatuhan dengan tuhan dalam menjalani kehidupan alam semesta ini.

\section{Tahap Perkembangan} Spiritual Menurut Moody

a. Tahap Pangilan (The Call) Tahap panggilan merupakan suatu tahap tumbuhnya kesadaran terhadap kekosongan diri dan ketidakmampuan untuk memenuhi tujuan kehidupan. Dalam menghadapi kepahitan hidup reaksi setiap orang berbeda.Orang-orang tertentu merasakan kekosongan hidup meskipun kehidupan terlihat berjalan baik. Ada suatu yang hilang dan membingungkan dalam kehidupan. Ketika panggilan untuk menjawab masalah ini datang, seorang memiliki dua pilihan: memilih komitmen diri untuk menjawab pangilan dengan jawaban pribadi atau menutup segala perasaan dan bertindak seperti biasanya sehingga ia tidak merasa tertekan. Kebanyakan orang memilih pilahan kedua, dan menumpuk masalah sehingga mereka menjadi lebih depresi. Jika individu mulai mempertanyakan penyebab kekosongan pada diir mereka dengan menjawab berbagai 
pertanyaan priabadi, mereka mulai proses perkembangan spiritual selanjudnya yang disebut dengan tahap pencarian (the search) untuk mencari kebenara diri.

b. Tahap Pencarian (The Search)

Tahap pencarian adalah titik dimana individu mulai mencari jalan spiritual dengan melihat kedalam dan mempertanyakan diri mereka berbagai pertanyaan serius tentang prinsip intergritas dan menguji kepercayaan inti mereka.

Maksudnya bahwa pada diri individu terus mencari jawaban, makna dan tujuan hidup, serta tempat yang mereka miliki.Orang-orang pada tahap ini menghubungkan dirinya mereka lebih pribadi dengan kepercayaan, komunitas, atau pemimpin spiritual yang dapat memberi nasehat dlam perjalanan mereka dan membantu mereka dalam mencapai jalannya.

c. Tahap Pergolakan (The Struggle)

Tahap pergolakan yang dimaksud disini adalah suatu tahap dimana individu dalam menemukan proses spiritual dalam memahami makna hidup, masing-masing individu mulai menyesuiakan diri terhadap pikiran dan prilaku yang membawa keluar dari konflik. Mulai dengan kegembiraan dan kegairahan seperti jika terlibat kisa asmara baru, mereka mulai mengikat diri pada gaya hidup baru. Hidup dengan menemukan hubungan baru dengan kehidupan menjadi tantangan yang berada didalam maupun diluar realitas.

d. Tahap Terobosan (The Breakthrough)

Tahap yang merupakan tahap pertangung jawaban pribadi ini melengkapi kebaikan dan makna yang diberikan dunia kepada semua orang. Pada tahap ini individu menumbuhkan kesatuan dan melakukan pertobatan.. Pengalaman pada tahap ini adalah kedamaian sejati.

Dapat disimpulakan menurut penulis tahap ini merupakan tahap dimana individu merasakan suatu kehidupan yang tenang, membawah kebaikan, kedamaian dan jalan keluar bagi sesamanya. 
e. Tahap Kembali (The Retturn) Tahap kembali merupakan suatu tahap trobosan resolusi yang sangat besar dan kejernihan mental yang baru atau dikenal dengan tahap kebangkitan dari tugas spiritual, karena orang-orang pada tahap ini bagun dalam keadaan mimpinya dan pada tahap ini individu telah menemukan pemahaman bahwa segalanya mengikuti keteraturan, dan segalanya seperti seharusnya terjadi sehingga terciptalah suatu diri individu yang tercapai ketenangan dan kebahagiaan dan kedamaian.

\section{Tahap}

Perkembangan

\section{Spiritual Sufistik}

Menurut islam, manusia yang lahir dengan jiwa yang suci (nafsi zakiya). Namum, manusia juga lahir didunia dengan memiliki eksistensi fisik yang terdiri dari daging dan tulang. Keberadaan fisik manusia menimbulkan keterikatan dengan dunia tempat mereka tinggal dan dapat memberikan kegelapan serta dapat menutupi keindahan dan kebijaksanaan yang tersimpan dalam diri mereka. Pada asalnya, manusia dapat menjadi lupa dan terus-menerus hidup dalam kesombongan. Allah yang maha pengasih dan Maha Penyayang memberikan wahyu kepada manusia melalui kitap-kitab sucinya dan mengirimkan NabiNabinya untuk memimpin dan memberikan contoh bagi manusia untuk kembali menuju cahaya kebenaran dari kegelapan yang menutupi diri manusia.

Adapun tahapan

perkembangan spiritual sufistik yang penulis maksud adalah sebagai berikut: ${ }^{32}$

a. Nafs Ammarah (The Commanding Self)

Godaan untuk melakukan kejahatan merupakan hal umum yang terjadi pada setiap manusia. Individu yang berada pada tahap ini adalah orang nafsunya didominasi godaan yang mengajaknya kearah kejahatan.

Dengan demikian menurut penulis pada tahap ini individu tidak dapat mengontrol kepentingan dirinya dan tidak memiliki moralitas atau perasaan kasih. 
Pada tahap ini pula kesadaran dan akan manusia dikalahkan oleh keinginan dan nafsu hewani. Manusia tidak menghargai batasan moral untuk mendapatkan apa yang di inginkan.

b. Nafs Lawwamah (The Regreful Self)

Tahap ini merupakan suatu tahapan dimana individu mulai memiliki kesadaran terhadap perilakunya, ia dapat membedakan yang baik dan yang benar, dan menyensali kesalahan-kesalahanya.

Namun ia belum memiliki kemampuan untuk mengubah gaya hidupnya dengan cara signifikan, misalnya individu seperti pencandu yang mulai memahami rasa sakit yang mereka sebabkan bagi diri mereka dan orang lain, namun kecanduan yang terlalu kuat untuk membuat mereka dapat berubah. Mereka membutuhkan obat yang lebih kuat. Sebagai langka wal ia mencobauntuk mengikuti kewajiban yang diberikan agamanya ,seperti sholat, berpuasa, membayar zakat, dan mencoba berperilaku baik. 33

Dengan demikian menurut penulis tahap ini merupakan suatu tahapan yang di ambang suatu kesadaran dimana individu mulai mengetahui mana yang baik dan mana yang buruk dan sangat menyadari akan perbuatan yang dilakuakan, Apabila perbuatan itu salah maka individu tersebut sangat menyesali akan perbuatan tersebut.

c. Nafs Mulhimah (The Inspired Selft)

Pada tahap ini individu mulai mulai merasakan ketulusan dari ibadahnya. Ia benar-benar termotivasi pada cinta kasih, pengabdian dan niali-nilai moral. Adapun perilaku pada tahap ini adalah kelembutan, kasih sayang,kreativitas, dan tindakan moral. secara keseluruan orang yang berada pada tahap ini memiliki emosi yang matang, menghargai dan dihargai orang lain.

d. Naf Muthma'innah (The Contented Self) 
Tahap ini dikenal dengan tahap kedamaian.Pergolakan pada tahap awal telah lewat. Kebutuhan dan ikatan-ikatan lama tidak lagi penting. Kepentingan diri mulai lenyap, membuat seorang lebih dekat dengan Tuhanya. Tingkat ini membuat seorang menjadi berfikir terbuka, bersyukur, dapat dipercaya, dan penuh kasih sayang. Jika seorang menerima segala kesulitan dengan kesabaran dan ketakwaan, tidak berbeda ketika ia memperoleh kenikmatan, dapat dikatakan bahwa seorang telah mencapai tingkat jiwa yang tenang. Penjelasan di atas seuai dengan contoh yang diberikan Muhamad SAW. Ia memiliki kualitas perilaku yang tinggi, seperti pengasih, pemurah, sabar, pemaaf, iklas, bersyukur, bahagia, dan damai.

e. Nafs Radhiyah (The Pleased Self)

Pada tahap ini individu tidak hanya tenang dengan dirinya, namun tetap bahagia dalam keadaan sulit, musibah atau cobaan dalam kehidupanya. Ia menyadari segala kesulitan datangnya dari Allah untuk memperkuat imannya. Keadaan bahagia tidak bersifat hedonistik atau materialistik, dan sangat berbeda dengan hal-hal yang biasa dialami orang-orang yang berorientasi pada halhal yang bersifat duniawi, prinsif memenuhi kesenagan dan menghidari rasa sakit.

f. Nafs Mardihiyah (The Self Pleasing to God)

Tahap ini merupakan suatu tahap yang dikenal dengan tahap mencapai kesatuan internal. Dimana pada tahap awal, seorang mengalami pergolakan, karena mengalmi keterpecahan. Kaca yang pecah menghasilkan ribuan bayangan dari satu pencitraan. Jika kaca menjadi satu kembali, akan melihat bayangan yang utuh, kesatuan pencitraan. Dengan menyembuhkan

keterpecahan dalam dirinya, seorang sufi mengalami dunia sebagai kesatuan yang utuh.

Tahap ini termanifestasi melalui ikatan antara sang 
pencipta (khalik) dengan yang diciptakanya, melaui perasaan cinta yang mendasari. Sang pencipta menemukan manusia yang sempurna dalam kualitas yang dianugrahi-Nya ketika ia menciptakanya.

g. Nafs Safiyah (The Pure Self)

Mereka yang telah mencapai tahap ini telah mengalami transendensi diri yang sutuhnya. Tidak ada nafs yang tersisa, hanya penyatuan dengan Allah. Pada tahap ini, seorang telah menyadari Kebenaran sejati. "Tidak ada tuhan selain Allah". Ia sekarang menyadari bahwa tidak ada apa-apa lagi kecuali Allah, dan hanya keillahianya yang ada, dan setiap indra manusia atau keterpisahan adalah suatu ilusi ${ }^{34}$.

Dari beberapa tahapan perkembangan sufistik spiritual yang telah dikemukan di atas dapat penulis simpulkan bahawa tahap tersebut mencermikan bahwa pada diri individu memiliki tingkatan spiritualitas. Dimana Individu yang mencari jalanya harus menyadari karakter dan perilaku dirinya secara jujur, sebelum naik ketingkat yang lebih tinggi.Individu juga harus memahami dimana keberadaannya sehingga ia harus mengenal karakteristik masing masing tingkatan yang telah dijelaskan di atas khusunya pada tingkatan dimana ia nantinya akan berada.

\section{Perkembangan Spiritual Pada Remaja}

Perkembangan kehidupan spiritual pada remaja tidak dapat dilepaskan oleh pembinaaan kepribadian secara keseluruan. Karena kehidupan spiritual remaja adalah bagaian dari kehidupan sendiri, sikap atau tindakan seorang dalam hidupnya tidak lain dari panutan pribadinya yang bertumbuh dan berkembang sejak ia lahir, semenjak berada dalam kandungan ${ }^{35}$. Semua pengalaman dilalui sejak dalam kandungan, mempunyai pengaruh terhadap pertumbuhan pribadi bahkan diantara ahli jiwa ada yang berpendapat pribadi tiu tidak lain adalah kumpulan 
pengalaman pada usia-usia terdahulu. 36

Masa remaja dalam hal ini merupakan suatu masa yang sangat kritis artinya pada diri remaja tidak saja mengalami kestabilan psikologis akan tetapi remaja juga mengalami kestabialan emosi dalam diri yang ckup kuat.. dalam hal ini perlu kita ketahui bahwa mas aremaja bukan berarti seorang anak lepas sama sekali dari ciriciri yang dimilki pada masa sebelumnya,dalam pengertian pada masa ini juga remaja dekat akan mudah bunuh diri, pemberang dan putus asa jika kehendaknya terhalangi dalam gambaran umum, Umar Hasyim melukiskan sebagai berikut ;

"Masa ini bisa dikatakan sebagai masa transisi, dan ini bisa merupakan masa yang berbahaya baginya, sebab ia mengalami hidup dua alam, yakni antara alam khayalan dan alam kenyataan, dimana banyak ditemukan gejolak jiwa dan fisik. Transisi merupakan pindahan dalam khyalan ke dalam alam nyata, yang mana banyak kaum remaja berkhayal bahwa dirinya merupakan sefr hero dalam segala hal..........
Gejola emosional yang tidak terkendali akan membawahnya ke alam yang khayal dan nyatanya tidak. ${ }^{37}$

Disinilah kalau kita lihat banyak para remaja yang yang menjadi nakal karena ingin membuktikan bahwa dirinyaan itu telah dewasa, padahal sebenarnya belum apa-apa, karena kedewasaan itu tidak hanya pada fisik akan tetapi meliputi keseluruhan mental dan kejiwaan yang di istilakan juga oleh penulis yaitu spiritual yang matang.

Selain itu pada masa remaja, seorang anak belum dapat memilki kestabialan perasaan dan emosi. Ketidakstabilan tersebut nampak jelas dalam berbagai sikap, dalam arti lain mereka belum dapat menentukan arah masa depan, menentukan bidang perkerjaaan yang pailng sesuai dengan bidang keahlianya, bahkan kadang-kadang tidak dapat menentukan sendiri lanjutan pendidikannya. Dalam hal ini seorang ahli Granville Hall Mengemukakan ;

Masa ini sebagai perasaan yang sangat peka, remaja mengalmai badai dan topan dalam kehidupan perasaan dan emosinya. 
Keadaan semacam ini diistilahkan sebagai "storm and stress. Tidak aneh lagi bagi orang yang mengerti kalau melihat sikap dan sifat remaja yang sesekali sangat bergairah dalam berkerja tiba-tiba berganti lesuh, kegembiraan yang meledak bertukar rasa sedih yang sangat, rasa yakin diri berganti rasa ragu yang berlebihan. ${ }^{38}$

Dari pendapat di atas dapat kita pertegas bahwa pada diri remaja akan mengalami suatu ketidakstabilan emosi dan perasaan, dimana dalam waktu bersamaan remaja akan mengalami masa kritis. Dimana remaja akan mengalami persolan-persoalan apakah dirinya akan mampu menyelesaikan permasalahan yang dihadapi atau tidak. Jika remaja itu mampu memecahkan permasalahan yang dihadapi maka akan mampu pula untuk selanjudnya, Sebaliknya bila remaja tidak mampu memecahkan permasalahan yang dihadapi maka ia akan menjadi remaja yang senantiasa mengantungkan diri dengan orang lain.

Dengan demikian Tampa mengetahui masalah-masalah tersebut maka akan sukarlah memahami sikap dan tingka laku spiritual pada remaja. Betapah banyak orang tua yang mengeluh, karena anaknya telah remaja itu telah menjadi keras kepala, sukar diatur, mudah tersingung dan melanggar aturan atau niali nilai moral atau norma-naorma yang berlaku.

Disamping itu tidak sedikit pula jumlah remajaremaja yang tidak mendapat tempat dalam masyarakat dewasa sehingga mereka mencoba jalan sendiri untuk membelah dan mepertahankan harga diri. Maka ditentanglah nilai yang dijunjung remaja oleh masyarakat.

\section{Perkembangan Spiritual Keberagamaan pada Diri Remaja}

Dalam pembagian tahap perkembangan manusia, maka masa remaja menduduki tahap progresif, ${ }^{39}$ Dalam kamus bahasa indonesia progresif dikenal dengan tahap dimana diri individu telah mengalami kemajuan;bertingkat-tingkat naik. ${ }^{40}$ Dengan demikian menurut penulis remaja yang progresif adalah suatu masa remaja yang mana telah mengalami kemajuan atau 
perkembangan pada diri baik secara fisikologis maupun biologis. Dalam pembagian agak terurai masa remaja mencakup masa Juvenilitas (adolescantium),pubertas dan nubilitas.

Sejalan dengan perkembangan jasmani dan ruhaninya. Maka agama pada remaja turut di pengaruhi perkembangan itu. Maksudnya penghayatan para remaja terhadap ajaran agama dan tindak keagamaan yang tampak pada remaja banyak berkaitan dengan paktor perkembangan.

Faktor perkembangan jiwa keberagamaan pada remaja itu antara lain adalah;

\section{a. Pertumbuhan Pikiran dan Mental}

Ide dasar dan keyakinan yang telah diterima semenjak kecil akan berkembang dan bertambah subur, apabila dalam perkembangannya ia tidak mendapat kritikankritikan. Apa yang tumbuh dari kecil itu akan menjadi keyakinan yang dipengaruhinya melalui pengalaman-pengalaman yang dirasakannya.

Pertumbuhan

dan perkembangan agama yang dialami remaja sejalan dengan pertumbuhan kecerdasan. Pemikiran-pemikiran yang abstrak seperti adanya akhirat, surga dan neraka baru dapat dimengerti apabila pertumbuhan kecerdasannya telah memungkinkan untuk itu. Alfred Binet, seorang Psikolog Prancis (1857-1911) menyatakan bahwa kemampuan untuk mengerti masalah-masalah yang abstrak tidak sempurna sebelum mencapai usia 12 tahun dan kemampuan untuk mengambil keputusan baru yang dilihat berdasarkan fakta yang ada, akan dialami pada umur 14 tahun. Oleh karena itu pada masa ini mereka sudah dapat menolak saransaran yang tidak difahaminya dan berani untuk mengkritik pendapat-pendapat yang tidak sesuai dengan pemikirannya.

Setelah perkembangan mental mampu untuk menerima atau menolak pengertian-pengertian yang abstrak, maka pandangannya terhadap alam dan isinya 
berubah, dari mau menerima tanpa mengerti menjadi menerima dengan analisa. Perkembangan mental remaja ke arah berpikir logis (falsafi) ini lah yang mempengaruhi pandangan dan kepercayaan remaja terhadap adanya Tuhan.

Agama bagi remaja adalah hubungan antara dia, Tuhan dan alam. Perasaannya terhadap Tuhan merupakan pantulan dari sikap jiwanya terhadap alam luar, dapat dikatakan bahwa agama merupakan hasil dari interaksi antara dia dan lingkungannya. Sedangkan gambaran tentang Tuhan dan sifat-sifatnya dipengaruhi oleh kondisi perasaan dan sifat remaja itu sendiri.

\section{b. Perkembangan Perasaan}

Berbagai perasaan telah berkembang pada masa remaja. Perasaan sosial, etnis dan estetis mendorong mereka untuk menghayati kehidupan yang terbiasa dalam lingkungannya. Kehidupan religius akan cenderung mendorong dirinya lebih dekat ke arah hidup yang religius pula. Sebaliknya bagi remaja yang kurang mendapat pendidikan dan siraman rohani akan lebih mudah didominasi dorongan seksual. Mengingat pada masa ini remaja sedang mengalami kematangan seksual, maka perasaan ingin tahu dan super penasaraan yang tak ternetralisir terkadang dapat mengakibatkan mereka lebih mudah terperosok ke arah tindakan seksual yang menyimpang.

\section{c. Pertimbangan Sosial}

Perilaku keagamaan para remaja juga ditandai oleh adanya pertimbangan sosial. Dalam kehidupan keagamaan mereka timbul konflik antara pertimbangan moral dan material. Mereka sangat bingung dalam menentukan pilihan. Kehidupan duniawi lebih dipengaruhi oleh kepentinga materi, maka jiwa para remaja cenderung materialistis.

Hasil penyelelidikan Ernest Harms. Menyatakan bahwa $70 \%$ dari 1789 remaja Amerika antara usia 18-29 tahun, pemikiran mereka ditujukan bagi kepentingan: keuangan, kesejahteraan, kebahagiaan, kehormatan diri 
dan masalah kesenangan pribadinya.

\section{d. Perkembangan Moral.}

Pembinaan moral terjadi melalui pengalamanpengalaman dan kebiasankebiasaan yang ditanamkan sejak kecil oleh orang tua sesuai dengan nilai-nilai moral. Dalam pembinaan moral, agama mempunyai peranan yang penting, karena nilai-nilai moral yang datang dari agama bersifat tetap tidak berubah dimakan waktu dan tempat. Misalnya dalam kasus anak muda yang berlawan jenis berciuman di tempat umum, mungkin bila dinilai dari kacamata masyarakat, pendapatnya akan berbeda-beda. Orang Amerika menganggap itu hal yang biasa, namun bagi orang Indonesia hal tersebut sangat tidak sopan. Namun bila dilihat dari kacamata agama (agama Islam) perbuatan yang mendekati perbuatan zina adalah hal yang terlarang apalagi sampai zina di depan umum.

Perkembangan moral pada remaja dipengaruhi dari rasa berdosa dan usaha untuk mencari perlindungan.
Mereka rajin beribadah karena rasa bersalah (dosa). Semakin besar dosanya, semakin banyak ibadahnya dan sebaliknya, apabila rasa dosa itu berkurang maka ibadahnya juga menurun. Contoh kasus, seorang mahasisiwa mengeluh tidak bisa belajar dan berkonsentrasi karena seringkali berbuat dosa-dosa kecil dalam pergaualan dengan teman eratnya seorang wanita yang masih duduk di sekolah menengah. Setiap bertemu selalu melakukan dosa kecil, dan sesudahnya dia menyesal dan shalat untuk mohon ampun kepada Tuhan dan berjanji tidak akan mengulanginya lagi. Namun ketika bertemu lagi lalu dia melakukan lagi hal yang sama. Demikian pengakuan remaja yang sedang kebingungan karena merasa bersalah dan mengakui yang dilakukannya adalah salah, tetapi tidak mampu mengendalikan diri dari perbuatan salah tersebut. Maka do'a dan shalatlah yang sering menjadi tempat pelariannya. 
Dengan demikian dapat dilihat tipe moral yang nampak pada remaja, mencakup; ${ }^{42}$

a) Self-directive, taat terhadap agama atau moral berdasarkan pertimbangan pribadi.

b) Adaptive, mengikuti situasi lingkungan tanpa mengadakan kritik

c) Submissive, merasakan adanya keraguan terhadap ajaran moral dan agama.

d) Unadjusted, belum meyakini akan kebenaran ajaran agama dan moral.

e) Deviant, menolak dasar dan hukum keagamaan serta tatanan moral masyarakat.

\section{e. Sikap dan Minat}

Sikap dan minat remaja terhadap masalah keagamaan dapat dikatakan sangat kecil dan hal ini tergantung dari kebiasaan masa kecil serta lingkungan agama yang mempengaruhi mereka (besar kecil minatnya).

Dengan demikian dapat ditarik kesimpulan bahwa perasaan remaja dalam beragama, khususnya terhadap Tuhan tidaklah tetap. Kadang-kadang sangat cinta dan percaya kepadaNya, tetapi sering pula berubah menjadi acuh tak acuh bahkan menentang, dan perasaan ambivalensi inilah yang menjadi ciri khas dari jiwa keberagamaan remaja.

\section{Faktor Yang Mempengaruhi Perkembangan Spiritual Remaja}

Sikap keagamaan adalah suatu kondisi diri seorang yang dapat mendorongnya untuk bertingka laku sesuai dengan kadar ketaatanya terhadap agama. Sikap keberagamaan tersebut disebabkan oleh adanya konsitensi antara kepercayaan terhadap agama sebagai unsur konitif, perasaan terhadap agama sebagai unsur efektif, dan perilaku terhadap agama sebagai unsur konatif.

Dari sinilah dapat disimpulkan bahwa sikap keagamaan merupakan integrasi secara kompleks antara pengetahuan agama, perasaan agama, serta tindak keagamaan dalam diri seorang. Hal ini menunjukan bahwa sikap keagamaan menyakut atau berhubungan erat dengan kejiwaan. 
Berdasarkan kenyataan yang ada jadi sikap keagamaan sesorang pada remaja dipengaruhi oleh dua faktor yaitu faktor interen dan faktor eksteren.

1. Faktor Interen

a. Faktor Hereditas

Faktor hereditas yang dimaksud adalah suatu suatu sifat keturunan dari sifat genetik dari orang tua ke anak, ${ }^{43}$ artinya jiwa keagamaan pada remaja itu juga dipengaruhi oleh faktor genetik, sesuai yang dikemukan oleh Rasululah Muhamad SAW beliau berkata untuk memilih pasangan hidup yang baik dalam membina rumah tangga, sebab menurut beliau keturunan itu mempengaruhi bagi perkembangan jiwa keagamaan seorang.Benih yang berasal dari keturunan tercela dapat mempengaruhi sifat-sifat keturunan berikutnya. Oleh karena itu berikutnya Rasulullah SAW menyatakan, "Hati-hatilah dengan Hadra al-Diman, yaitu wanita cantik dari lingkungan yang jelek". Hampir sama yang dikemukakan oleh
Frued bahwa perbuatan buruk dan tercela akan menimbulkan suatu perasaan bersalah dalam diri pelakunya. Perasaan itu yang barangkali ikut mempengaruhi jiwa keagamaan seseorang sebagai unsur herditas. ${ }^{44}$

b. Tingkat Usia

Tingkat usia menurut berbagai ahli mengemukan bahwa adanya suatu keterkaitan tingkat usia dengan jiwa keagamaan yang tejadi pada diri peribadi, sesuai dengan yang dikemukakan oleh Ernest Harms bahwa Perkembangan agama pada anak-anak ditentukan oleh tingkat usia mereka, Karena perkembangan tersebut dipengaruhi oleh berbagai asfek kejiwaan, termasuk perkembangan

berfikir.Ternyata anak yang mengijak usia berfikir kritis lebih kritis pula dalam memahami ajaran agama. Selanjutnya pada usia remaja saat mereka merajak pada usia kematangan seksual, pengaruh itupun menyertai perkembangan jiwa keagamaan mereka. ${ }^{45}$ 
Tingkat perkembangan usia dan kondisi yang dialami para remaja menimbulkan konflik kejiwaan, yang cendrung mempengaruhi terjadinya konversi agama. Terlepas dari ada tidaknya hubungan konversi dengan tingkat usia seorang dengan perkembangan jiwa keagamaan barang kali tak dapat diabaikan begitu saja.Yang jelas, kenyataanya kita dapat melihat adanya suatu perbedaan pemahaman keagamaan pada tingkat usia yang berbeda.

c. Kondisi Kejiwaan

Menurut Sigmund Frued ganguan kejiwaan ditimbulkan oleh konflik yang terletak di alam ketidak sadaran manusia. Konflik akan menjadi sumber gejala kejiwaan yang abnormal. Artinya gejala jiwa yang abnormala ini juga muncul disebakan adanya faktor genetik atau kondisi sitem syaraf yang diperkirakan munculnya perilaku abnormal. 46

Gejala-gejala abnormal ini besumber dari kondisi
syaraf,Kejiwaan, dan kepribadian. Kondisi kejiwaan yang bersumber dari neurose ini menimbukan gejala kecemasan neurose, absesi, dan kommpulsi serta amnesia. Kemudian kondisi kejiwaan yang disebabkan oleh gejala psikosis umumnya menyebabkan seorang kehilangan kontak hubungan dengan dunia nyata.

2. Faktor Eksteren

a. Lingkungan Keluarga

Menurut teori Sigmund Frued dengan konsep Father Image beliau mnyatakan bahwa perkembangan jiwa keagamaan pada anak di pengaruhi citra anak terhadap bapaknya. Jika seorang bapak menunjukan sikap dan tingka laku yang baik, anak akan cendrung mengindentifikasikan sikap dan tingka laku sang bapak pada dirinya. Demikian pula sebaliknya, jika bapak menampilkan sikap buruk, hal tersebut juga akan ikut berpengaruh terhadap pembentukan perilaku pada anak. ${ }^{47}$

Dari teori diatas telihat jelas kedua orang tua 
Perkembangan Spiritual Remaja dalam Perspektif Ahli

sangat mempengaruhi perkembangan jiwa keagamaan anak. Dalam pandangan islam ini sudah lama disadari misalnya disini orang tua dianjurkan mengazankan ketelinga bayi yang baru lahir, mengadakan akikah, memberi nama yang baik dengan mebaca AlQur'an , membiasakan sholat serta bimbingan lainya yang sejalan dengan perintah agama.Dengan demikian keluarga disini dinilai sebagai faktor yang paling dominan dalam meletakkan dasar perkembangan jiwa keagamaan.

b. Lingkungan Institusional

Lingkungan institusional yang dimaksud disini adalah suatu lingkungan yang berupa institusi formal seperti sekolah dan non formal seperti perkumpulan dan organisasi.

Menurut Singgih Gunarsah pengaruh jiwa keagamaan terhadap keagamaan pada remaja dipengaruhi oleh tiga hal yaitu kurikulum dan anak, hubungan murid dan guru, dan hubungan antara anak. 48 Dari ketiga hal tersebut terlihat adanya suatu keterkaitanya denga perkembangan jiwa keagamaan yang mana tampak adanya ketiga hal tersebut ikut mempengaruhinya.Sebab pada frinsipnya perkembangan jiwa keagamaan tak dapat dilepaskan dari upaya untuk membentuk kepribadian yang luhur. Dalam ketiga hal tesebut terirat beberapa hal yang membentuk suatu sikap seperti ketekunan, disiplin, kejujuran, simpati, stabilitas, toleransi, keteladanan, sabar dan keadilan. Kesemu itu merupakan suatu hal yang yang menjadi bagian dari program sekolah.

c. Lingkungan Mayarakat

Lingkungan masyarakat adalah suatu lingkungan dimana kita besosialisai dan berinteraksi terhadap individu yang satu dengan yang lain. Dapat dikatakan bahwa seorang anak setelah mengijak usia sekolah, sebagaian besar bahwa waktu bermainyan dihabiskan dilingkungan masyarakat. Artinya 
lingkungan masyarakat itu pada umumnya merupakan bagian dari pembentukan sikap dan karakter pada diri anak. Pada umumnya pergaulan dimasyarakat kurang menekankan pada disiplin atau aturan yang harus dipatuhi secra ketat. Menurut

Barnadid lingkungan masyarakat adalah suatu lingkungan dimana lingkungan yang mengandung unsur tagung jawab, melainkan hanya merupakan unsur pengaruh belaka. ${ }^{49}$ Tetapi norma dan tata nilainya yang ada terkadang lebih mengikat sifatnya. Bahkan pengaruh jiwa keagamaanya lebih besar baik dalam bentuk positif maupun negatif. Misalnya lingkungan masyarakat yang memiliki tradisi keagamaan yang kuat akan berfengaruh positif bagi perkembangan jiwa keagamaan anak. Sebab kehidupan keagamaan terkondisi dalam tantanan nilai dan institusi keagamaan. Keadaan seperti inilah bagaimanapun akan berpengaruh dalam pembentukan jiwa keagamaan.

Dengan demikian dapat kita simpulkan bahwa lingkungan masyarakt memiliki suatu peranan penting dalam pembentukan jiwa keagamaan yang nantinya akan berdapak pada sikap dan perilaku sehingga perilaku yang ditampilkan dapat diterima dalam kontek sosial.

\section{Kesimpulan}

Dari uraian para ahli diatas dapat disimpulkan bahwa perkembangan spiritual remaja tidak dapat dilepaskan oleh pembinaan kepribadian secara keseluruhan. Karena perkembangan spiritual remaja adalah bagian dari kehidupan sendiri. Artinya sikap dan keyakinan spiritual seorang dalam hidupnya tidak lain dari panutan pribadinya yang bertumbuh dan kembang sejak lahir terutama semenjak dalam kandungan. Berkaitan dengan implikasi spiritual remaja dalam mencapai perkembangan identitas diri. Intinya pada diri remaja terdapat suatu sikap dan keyakinan yang diperoleh dari pengalama-pengalaman 
terdahulu. Artinya konsep keyakinan spiritual itu terbentuk atas pengalaman-pengalaman yang telah terjadi yang akhirnya akan berpengaruh terhadap identitas diri selanjutnya.

\section{Refrensi}

Bengkulu

${ }^{1}$ Dosen FUAD IAIN

${ }^{2}$ Alia B. Purwakania

Hasan, Psikologi Perkembangan

Islam, (Jakarta: Raja Grapindo, 2008). hal. 288

${ }^{3}$ Em Zul Fikri, Kamus

Lengkap Bahasa Indonesia,

(Jakarta: Difa Publisher). Hal. 771

${ }^{4}$ J.P Chaplin, Kamus

lengkap Psikologi,

(Jakarta:Rajawali Pers, 1989). hal. 480

${ }^{5}$ Alia B. Purwakania

Hasan, Op, Cit. hal. 289

${ }^{6}$ Ibid,. hal. 289

${ }^{7}$ Ary Ginanjar Agustian,

Rahasia Sukses Membangun

Kecerdasan Emosi \& Spiritual

ESQ, (Jakarta: $\quad$ Agra, 2001). hal. 57

${ }^{8}$ Ary Ginanjar Agustian,

Rahasia Sukses Mmebangkitkan

ESQ POWER, ( Jakarta: Agra,

2003). hal. 97

${ }^{9}$ Abdul Wahid Hasan,

Kecerdasan Spiritual (SQ)

Rasulullah Masa Kini,

(Jojakarta:Ircisod, 2006). hal. 85

${ }^{10}$ Hendra Harmi,

Kecerdasan Intelektual \& Spiritual

Terhadap Hasil Belajar Siswa SMA

Padang, (Curup: STAIN Curup,

2005). hal. 15

$$
{ }^{11} \text { Ibid,. }
$$

${ }^{12}$ Abdul Wahid Hasan,

Op, Cit. hal. 62

${ }^{13}$ Ibid, hal. 62-63
${ }^{14}$ Ibid,.
${ }^{15}$ Suharsono, Melejitkan

IQ, EQ, SQ, (Jakarta: Ummah

Publishing, 2009), hal. 6

${ }^{16}$ Melly Oktasari, Peranan

Keluarga Islam Dalam Mmembina

Kecerdasan Spiritual Anak,

(Curup: Skripsi STAIN Curup,

2010). hal. 32

${ }^{17}$ Ary Ginanjar Agustian,

Op, Cit. hal. 96

${ }^{18}$ Ibid,.

${ }^{19}$ Al Qur'an dan Tafsir,

Departemen Agama RI, (Bandung

dipenogoro. 2013)...

${ }^{20}$ Yahya Jaya,

Spiritualisasi Islam Dalam

Menumbuh Kembangkan

Kepribadian Dan Kesehatan

Mental, (Jakarta:Ruhama, 1994).

hal. 8

${ }^{21}$ Sustrisan Sumadi, hal.

54

${ }^{22}$ http://cominsyki.blogspo

t.com/2011/Spritulitsas.htm.

Diunduh pada tanggal 28

Desemberi 2018, pukul. 19.00

WIB

${ }^{23}$ Abdul Wahid Hasan,

Op, Cit. hal. 70

${ }_{26}^{24}$ Ibid,

http://yuanitaresti.blogspot.com/20

11/bab-i-pendahuluan.htm.

Diunduh pada tanggal 4 Februari

2019, pukul. 13.00 WIB

${ }^{27}$ Danah Zohar dan Ian

Marshall, $S Q$, (Bandung: Mizan, 200), hal. 14.

${ }^{28}$ Ary Ginanjar Agustian,

Op, Cit. hal.108-110 
${ }^{29}$ Aliah. B. Purwakania

Hasan, Op, Cit. hal.298

${ }^{30}$ Ibid,.
${ }^{31}$ Ibid,.
${ }^{32}$ Ibid,. 305
${ }^{33}$ Ibid.,
${ }^{34}$ Ibid.,
${ }^{35}$ Akmal Hawi, Ilmu Jiwa

Agama, (Palembang: Katalog

Dalam Terbitan (KDT), 2005) hal.

200.

${ }^{36}$ Ibid,.

${ }^{37}$ Sudarsono, Etika Islam

Tentang Kenakalan Remaja,

(Jakarta:Rineka Cipta,1986). hal.14

${ }^{38}$ Ibid,.

${ }^{39}$ H.Jalauddi, Psikologi

Agama, ( Jakarta: Rajawali Pres,

2005). hal 74-

${ }^{40}$ Em Zul Fikri, Kamus

Lengkap Bahasa Indonesia(

Jakarta:Difa Publiser,

2004).hal.672

${ }^{41}$ H.Jalaludin, "Psikologi

Agama”, (Jakarta: Raja Grafindo

Persada. 1997), hal. 72-75

Citl., Hal 69

${ }^{42}$ Bambang Samsul, $O p$.

${ }^{43}$ Em Zul Fajri, Kamus

Bahasa Indonesia, (Jakarta:Difa

Fubliser, 2009). hal.335

Op, Cit. hal 78

${ }^{44}$ Bambang Samsul Arifin,

${ }^{45}$ Ibid,. hal. 80

${ }^{46}$ Ibid,. hal. 82

${ }^{47}$ Ibid,. hal.83

${ }^{48}$ Ibid,. hal. 84

${ }^{49}$ Ibid,. hal. 85 